Topology

Band

$1.00-$

$0.75-$

$0.50-$

$0.25-$

0.00 -
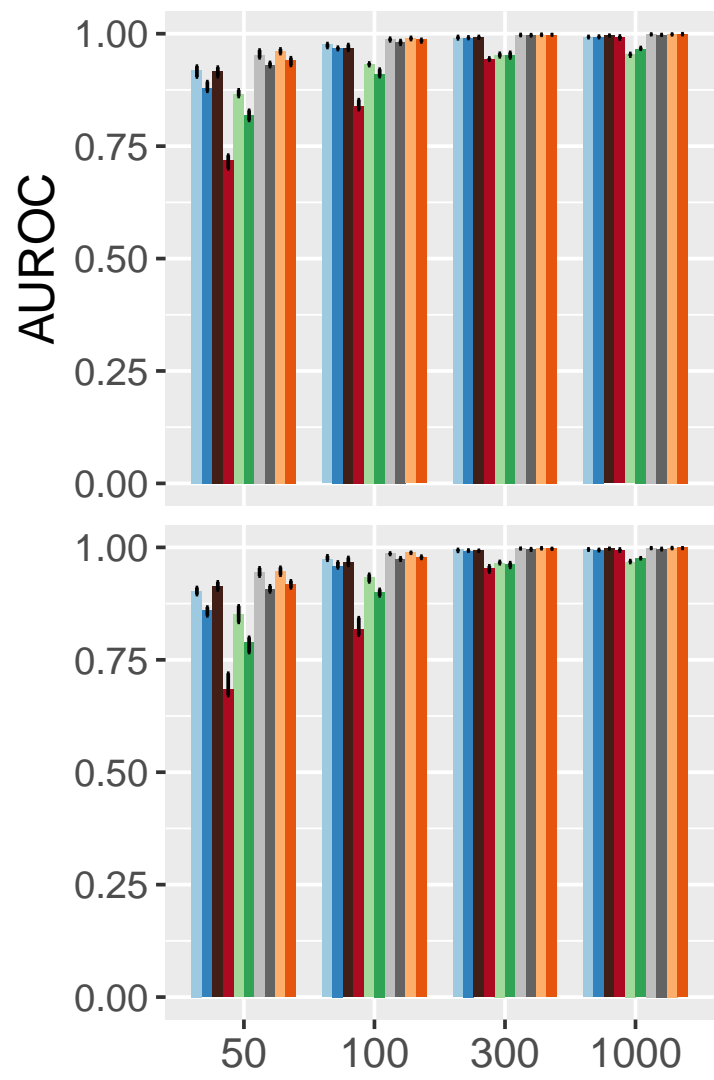

Erdos Renyi
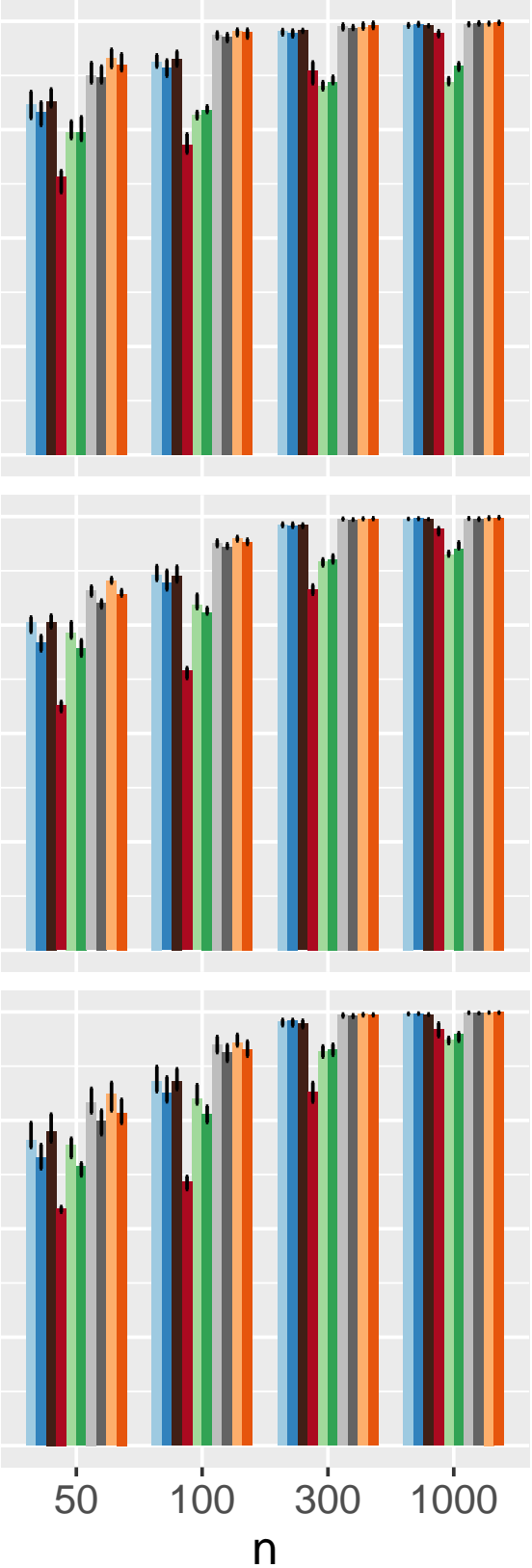

\section{Scale Free}
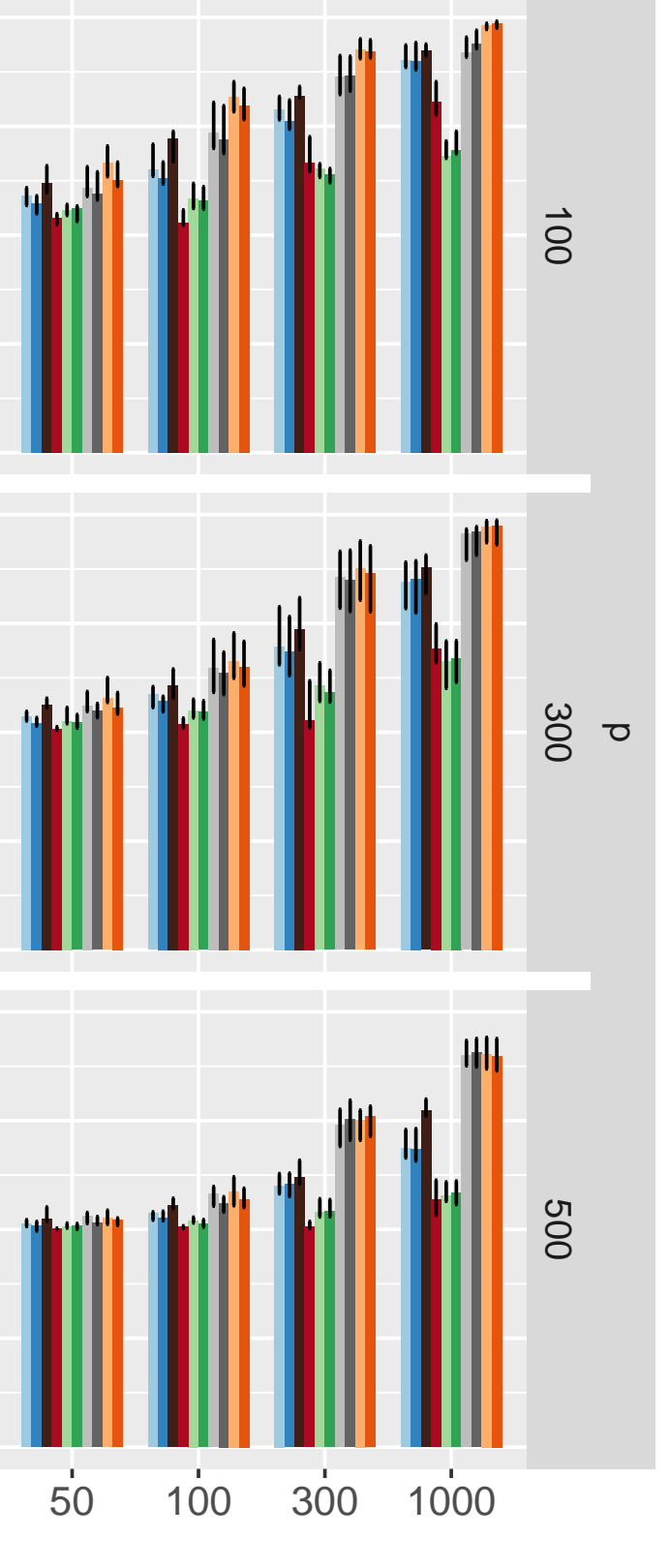

Sparcc

Flashweave
Raw-gLasso Raw-MB
MAGMA-gLasso MAGMA-MB
ZiLN-glasso ZiLN-mb 